\title{
Intrapartum amnioinfusion in meconium stained amniotic fluid at term pregnancy
}

\author{
Bharti Choudhary Parihar, Babli Yadav, Priyanka Sharde, Jaya Patel*
}

Department of Obstetrics and Gynaecology, GMC Bhopal, Madhya Pradesh, India

Received: 18 November 2020

Revised: 08 December 2020

Accepted: 09 December 2020

\author{
*Correspondence: \\ Dr. Jaya Patel, \\ E-mail: sunshinejaya@gmail.com
}

Copyright: () the author(s), publisher and licensee Medip Academy. This is an open-access article distributed under the terms of the Creative Commons Attribution Non-Commercial License, which permits unrestricted non-commercial use, distribution, and reproduction in any medium, provided the original work is properly cited.

\section{ABSTRACT}

Background: In our country a major cause of perinatal mortality and morbidity is meconium aspiration syndrome (MAS) in new-born. The aim of this study is to assess feto-maternal outcome following intrapartum amnioinfusion in patients with meconium stained amniotic fluid and the rate of ceaserean deliveries following intrapartum amnioinfusion in patients with meconium stained amniotic fluid.

Methods: This prospective observational study was conducted on 252 patients with pregnancy at or beyond 37 weeks in active labour with moderate to thick meconium stained amniotic fluid following spontaneous rupture or ARM. In such cases amnioinfusion was performed. Continuous electronic FHR monitoring was performed. Emergency LSCS was done when fetal Bradycardia was recorded or in case of non-progress of labor. Fetomaternal outcome will be noted.

Results: In present study most, women had normal vaginal delivery 157 (62.30\%) followed by LSCS 93 (36.91\%) followed by forceps/vaccum delivery $02(0.07 \%)$. No maternal complication was seen in 230 women $(91.26 \%)$. Accidenatal hemorrhage was seen in $01(0.39 \%)$ which was managed by emergency LSCS. Out of 252 neonates, 183 asymptomatic neonates at birth, 69 needed resuscitation and in which 52 neonates recovered and shifted back to mother and 17 neonates referred and admitted in NICU for MAS in which 07 were recovered and 10 neonates $(3.96 \%)$ died due to MAS.

Conclusions: Intrapartum amnio infusion in meconium stained amniotic fluid by diluting the meconium and by decreasing the cord compression decreases the incidence of foetal distress and there by decreases the rate of caesarean section, these all leads to decrease the incidence of maternal and perinatal morbidity and mortality.

Keywords: Meconium, Amniotic fluid, MAS, Amnioinfusion

\section{INTRODUCTION}

Meconium is the first intestinal secretions from fetus. It starts as early as ten weeks of gestation and incidence of intrauterine passage of meconium increases with the gestational age. Meconium reduces the antibacterial property of amniotic fluid by altering the level of zinc in it which leads to intra amniotic infections. Meconium stained amniotic fluid is a common obstetric situation occurring in $07-22 \%$ of women in labour. $5 \%$ in preterm pregnancy, up to $20 \%$ in term and $>20 \%$ in post term pregnancy. ${ }^{1,2}$ Meconium aspiration syndrome is believed to result from aspiration of meconium during intrauterine gasping or at the time of first breath. In case of hypoxia, gasping of fetus results in meconium aspiration which neutralizes the surfactant action and promotes inflammation of lung tissues, whereas persistent hypoxia after birth, aspirated meconium results in pulmonary hypertension. ${ }^{3}$ The aim of this study was to assess fetomaternal outcome following intrapartum amnioinfusion in patients with meconium stained amniotic fluid and the rate of ceaserean deliveries following intrapartum 
amnioinfusion in patients with meconium stained amniotic fluid.

\section{METHODS}

Detailed history taking, general physical examination and obstetric examination were done. All relevant investigations were sent. After explaining the procedure \& written informed consent amnioinfusion was done with a sterile catheter was introduced transcervically to a depth of $30 \mathrm{~mm}$, and a bolus of $600 \mathrm{ml}$ of sterile saline at room temperature was infused under the force of gravity at a rate of $20 \mathrm{ml} / \mathrm{min}$ over a period of $30 \mathrm{~min}$. More fluid was infused at the same rate till the returning fluid is clear or up to a maximum of $1,000 \mathrm{ml}$. Women were assessed by uterine palpation at 15-min intervals for uterine hypertonic contractions. In such cases, amnioinfusion was discontinued. Continuous electronic FHR monitoring was performed.

Augmentation for inadequate uterine contraction was done with use of oxytocin if there was a delay in the progress of labor and no fetal bradycardia recorded. Emergency LSCS was done when fetal Bradycardia was recorded or in case of non-progress of labor. Apgar scoring at 1 minute and 5 minutes was done.

The composite primary outcome measure was the occurrence of perinatal death, moderate or severe meconium aspiration syndrome, or both. In accordance with clinical criteria, the meconium aspiration syndrome was defined as respiratory distress in the first $4 \mathrm{~h}$ after birth and categorized as severe (requiring assisted mechanical ventilation) or moderate (requiring oxygen for at least $48 \mathrm{~h}$ at a concentration of $40 \%$ or greater but without mechanical ventilation). Secondary outcomes included perinatal death or maternal death or serious morbidity or both. Serious perinatal morbidity included moderate or severe meconium aspiration syndrome; hypotonia; assisted ventilation or intubation of more than 5 min duration; a 5 min Apgar score below 7; an umbilical-artery blood $\mathrm{pH}$ value below 7.05; abnormal consciousness; the need for tube feeding; convulsions; and a blood or lumbar culture positive for bacteria. Serious maternal morbidity included the presence of any of the following: uterine rupture, amniotic-fluid embolism, accidental hemorrhage requiring urgent delivery, postpartum hemorrhage requiring transfusion, hysterectomy, admission to the intensive care unit, or disseminated intravascular coagulation. All statistical analysis was done by SPSS 21 software.

\section{RESULTS}

In our study out of 252 pregnant womens, 164 women $(65.0 \%)$ were between $20-25$ years and 47 (18.6\%) were between 26-30 years age group (Figure 1). 164 (64.68\%) of these were primi, $82(32.53 \%)$ were multi gravida and $07(2.77 \%)$ were grand multi (Figure 2). The mean gestational age in study group is 40 weeks, out of 252 pregnant women, $159(63.09 \%)$ were in more than 40 week gestational age group and $93(36.90 \%)$ were in 3740 week gestational age group. It showed that postdatism causes passage of meconium during labour due to fetal maturity (Table 1).

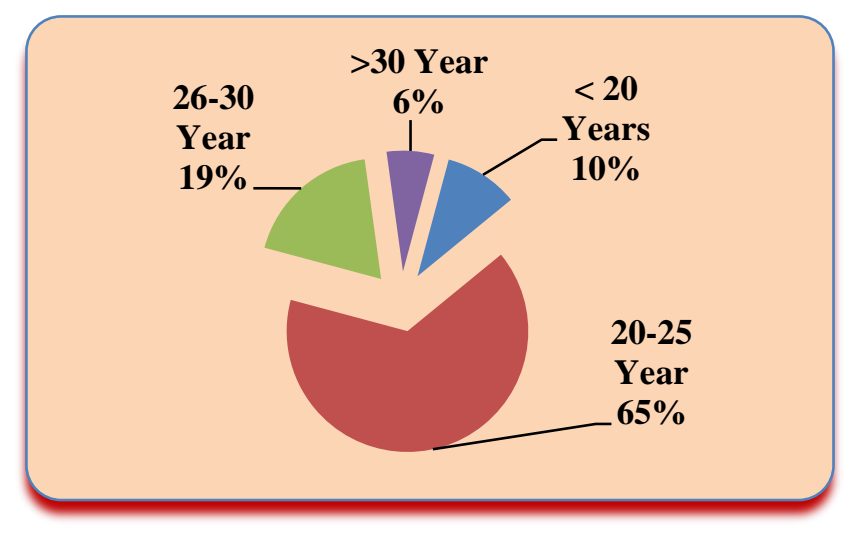

Figure 1: Age distribution.

Table 1: Gestational Age wise distribution of cases.

\begin{tabular}{|lll|}
\hline $\begin{array}{l}\text { Gestational age } \\
\text { (weeks) }\end{array}$ & $\begin{array}{l}\text { Number of cases } \\
(\mathbf{n = 2 5 2})\end{array}$ & $\begin{array}{l}\text { Percentage } \\
(\mathbf{1 0 0 \%})\end{array}$ \\
\hline $\mathbf{3 7 - 4 0}$ & 93 & 36.9 .0 \\
\hline $\mathbf{7 4 0}$ & 159 & 63.09 \\
\hline Total & 252 & 100.0 \\
\hline
\end{tabular}

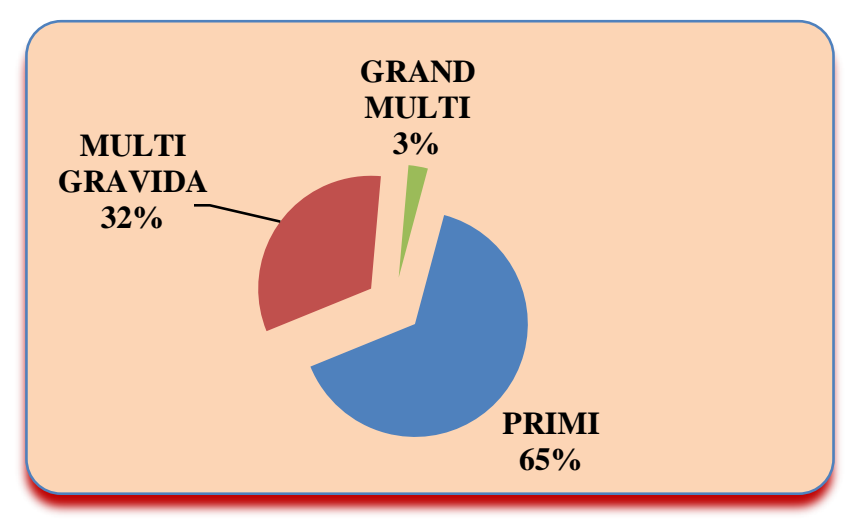

Figure 2: Obstetric index.

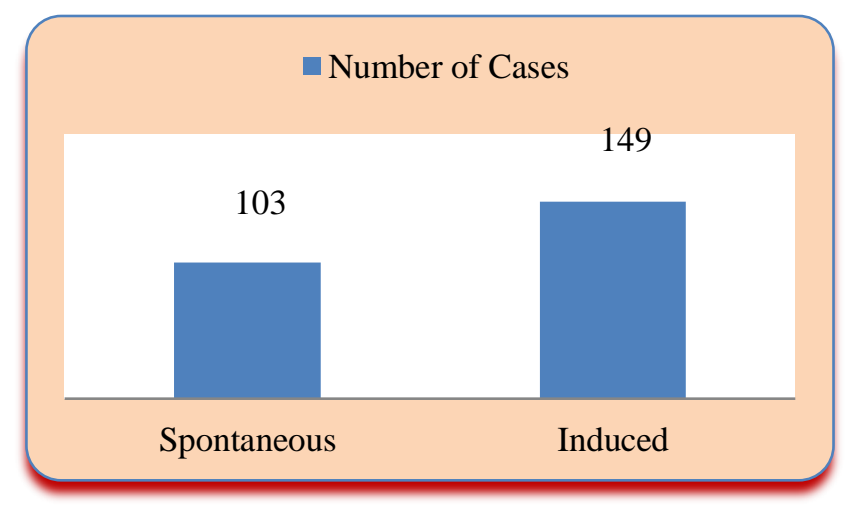

Figure 3: Onset of labour. 
It was observed that Out of 252 pregnant women, among $149(59.12 \%)$ labour was induced and among 103 $(40.86 \%)$ labor was spontaneous (Figure 3). In our study most of women are post-dated in which induction of labour was done, so it shows that induction of labour itself increases the risk of passage of meconium. Meconium in Amniotic fluid was detected at cervical dilatation of $5-6 \mathrm{cms}$ in $142(56.34 \%)$ women and at cervical dilatation of $3-4 \mathrm{cms}$ in $110(43.63 \%)$ women (Table 2).

Table 2: Cervical dilatation at the time of meconium detection.

\begin{tabular}{|lll|}
\hline $\begin{array}{l}\text { Cervical dilatation } \\
(\mathbf{c m})\end{array}$ & $\begin{array}{l}\text { Number of } \\
\text { cases } \\
(\mathbf{n = 2 5 2})\end{array}$ & $\begin{array}{l}\text { Percentage } \\
(\%)\end{array}$ \\
\hline $\mathbf{3 - 4}$ & 110 & 43.63 \\
\hline $\mathbf{5 - 6}$ & 142 & 56.34 \\
\hline Total & 252 & 100.0 \\
\hline
\end{tabular}

There was statistically significant difference found in amnioinfusion to delivery interval (Hrs) and obstetrics index $(\mathrm{p}=0.028)$ (Table 3).

There was statistically no significant difference found in distribution of study subjects according to mode of delivery and obstetrics index $(\mathrm{p}=0.243)$ (Table 4).

Table 3: Correlation of amnioinfusion to delivery interval (hrs) and obstetrics index.

\begin{tabular}{|lllll|}
\hline $\begin{array}{l}\text { Amnioinfusion } \\
\text { to delivery } \\
\text { interval (hrs) }\end{array}$ & $\begin{array}{l}\text { Primi } \\
\text { gravida }\end{array}$ & $\begin{array}{l}\text { Multi } \\
\text { gravida }\end{array}$ & $\begin{array}{l}\text { Grand } \\
\text { multi }\end{array}$ & Total \\
\hline $\mathbf{1 - 2}$ & 79 & 45 & 07 & 131 \\
\hline $\mathbf{2 - 3}$ & 54 & 30 & 00 & 84 \\
\hline $\mathbf{3 - 4}$ & 30 & 07 & 00 & 37 \\
\hline Total & 163 & 82 & 07 & 252 \\
\hline Chi square value & 10.9 & & \\
\hline Significant P value & $0.028(\mathrm{~S})$ & \\
\hline
\end{tabular}

Table 4: Mode of delivery and obstetrics index.

\begin{tabular}{|llll|l|}
\hline $\begin{array}{l}\text { Mode of } \\
\text { delivery }\end{array}$ & $\begin{array}{l}\text { Primi } \\
\text { gravida }\end{array}$ & $\begin{array}{l}\text { Multi } \\
\text { gravida }\end{array}$ & $\begin{array}{l}\text { Grand } \\
\text { multi }\end{array}$ & Total (\%) \\
\hline NVD & 94 & 57 & 06 & $\begin{array}{l}157 \\
(62.3)\end{array}$ \\
\hline $\begin{array}{l}\text { Forceps/ } \\
\text { vacuum }\end{array}$ & 01 & 01 & 00 & $\begin{array}{l}02 \\
(0.071)\end{array}$ \\
\hline LSCS & 68 & 24 & 01 & $\begin{array}{l}93 \\
(36.95)\end{array}$ \\
\hline Total & 163 & 82 & 07 & $\begin{array}{l}252 \\
(100.0)\end{array}$ \\
\hline Chi Square value & \multicolumn{3}{|c|}{5.46} \\
\hline Significant P value & \multicolumn{3}{|l}{0.243 (NS) } \\
\hline
\end{tabular}

Out of 252 neonates, 183 were asymptomatic and required only routine care at birth, 69 neonates needed resuscitation out of which 52 recovered and could be shifted back to mother however 17 neonates had to be admitted in NICU for meconium aspiration syndrome. Out of these 17 neonates, 7 recovered and shifted back to mother. Neonatal death was seen in 10 neonates $(3.96 \%)$ due to MAS (Table 5).

There was statistically highly significant difference in APGAR score at 1 and 5 minutes $(\mathrm{p}=0.001)$ (Table 6).

Table 5: Fetal outcome.

\begin{tabular}{|ll|}
\hline Foetal outcome & Number of cases \\
\hline $\begin{array}{l}\text { Asymptomatic } \\
\text { (routine care at birth) }\end{array}$ & 183 \\
\hline Needed resuscitation & 69 \\
\hline $\begin{array}{l}\text { Needed referral for meconium } \\
\text { aspiration }\end{array}$ & 17 \\
\hline Neonatal death & 10 \\
\hline
\end{tabular}

Table 6: APGAR score at 1 and 5 minutes.

\begin{tabular}{|lllll|}
\hline $\begin{array}{l}\text { APGAR } \\
\text { Score }\end{array}$ & \multicolumn{2}{c}{ At $\mathbf{1}$ minute } & \multicolumn{2}{c|}{ At 5 minutes } \\
\hline & Number & $\%$ & Number & $\%$ \\
\hline$<7$ & 106 & 42.06 & 59 & 23.41 \\
\hline$>7$ & 146 & 57.93 & 193 & 76.59 \\
\hline Total & 252 & 100 & 252 & 100.0 \\
\hline Chi square value & 19.9 \\
\hline Significance 'p' value & \multicolumn{2}{c|}{0.00} & (HS) \\
\hline
\end{tabular}

\section{DISCUSSION}

In contrast to our study, a Hospital based cross sectional study was conducted at Hiwat comprehensive specialized referral hospital in 2018 showed that mothers whose age greater than 30 years were 5.6 times more likely to develop MSAF during labour than those less than 30 years $(\mathrm{AOR}=5.6,95 \%, \mathrm{CI}=3.35-9.44) .{ }^{4}$ Oyelese et al conducted a retrospective cohort study and showed that rates of meconium stained amniotic fluid increased from $1.2 \%$ at 32 weeks to $100 \%$ at 42 weeks and concluded that rising incidence of meconium stained amniotic fluid with gestational age is consistent with the hypothesis that fetal maturation is a major etiologic factor in meconium passage. It was seen that passage of meconium was more in primigravida, $163(64.68 \%)$ as compared to multigravida $62(24.60 \%)$. Osava et al found that being multiparous was associated as a protective factor against the presence of meconium stained amniotic fluid $(33 \%$ lower risk), but only for women with a history of normal births. $^{5}$

It was observed that meconium stained amniotic fluid was more common in women in which labour was induced $149(59.12 \%)$ as compared to spontaneous onset of labour $103(40.86 \%)$. Samiyappa et al found that 
MSAF was more common in 118 women (52.2\%), in which Induction of labour was done as compare to 108 women $(47.8 \%)$ in which onset of labour was spontaneous. ${ }^{6}$ According to Hospital based cross sectional study was at Hiwat comprehensive specialized referral Hospital Obstetrics and Gynecology department, from March 02- May 27, 2018 showed that women who had induced labour were 2.6 times more likely to develop MSAF as compared to the spontaneous onset of labour $(\mathrm{AOR}=2.6,95 \% \mathrm{CI}=1.39-4.87) .{ }^{4}$ It was observed that in present study MSAF was more common in women with cervical dilatation $5-6 \mathrm{~cm}, 142(56.34 \%)$ followed by $3-4$ $\mathrm{cm}, 110$ (43.65\%). According to a study conducted by Parth et al average cervical dilatation at the time of detection of MSAF was $5.4 \mathrm{~cm}^{7}$

In present study most women had normal vaginal delivery 157 (62.30\%) followed by LSCS 93 (36.91\%) followed by forceps/vaccum delivery $02(0.07 \%)$. A lower caesarean section rate in the current study is possibly due to the fact that Amnioinfusion increases the volume of fluid around the fetus therefore decreasing the probability of foetal distress related to cord compression. This coincides with the studies by Pierce et al showed lower incidence of caesarean section in the amnioinfusion group $19.7 \%$ and instrumental delivery was $18 \%{ }^{8}$ Similar observations of lower incidence of operative deliveries have been made by several authors, Das et al showed $18 \%$ caesarean section rate in amnio infused group. ${ }^{9}$ Choudhary et al reported lower caesarean section rate of $31 \%$ in amnio infused group. ${ }^{10}$ Sahu et al also showed reduced caesarean section rate in amnio infused group. Das et al reported similar perinatal mortality rate of $1 \%$ in women with Amnioinfusion. ${ }^{9}$ Partha et al shows $1 \%$ perinatal mortality in Amnio infused group. ${ }^{11}$ In our study out of 252 women, no maternal complication was seen in 230 women (91.26\%). Accidental hemorrhage was seen in $01(0.39 \%)$ which was managed by emergency LSCS.

Postpartum hemorrhage was seen in 04 women $(1.58 \%)$ which was medically managed in 03 women and 01 were required bakri balloon insertion. Blood transfusion was done in 05 cases $(1.98 \%)$. Mahomed reported no complication related to Amnioinfusion procedure. ${ }^{12}$ Pueperal pyrexia seen in only 11 patients $(4.36 \%)$ out of 252 patients. The decrease in incidence of pueperal pyrexia probably due to dilutional effect on bacteria that enter the uterus. Rathore et al and Hofmeyr also found similar results. ${ }^{13,14}$ There was no cases of Amniotic fluid embolism and uterine hyperstimulation/ rupture seen in our study. In our study out of 252 neonates 183 neonates $(72.61 \%)$ are asymptomatic and required routine care at birth. 69 neonates $(27.38 \%)$ needed resuscitation. Asnani et al reported that $67.5 \%$ neonates required routine care and resuscitative measures required in only in $32.5 \%$ neonates in amnioinfused group. 49 out of 69 neonates 52 (20.6\%) neonates recovered and shifted back to mother and $17(6.7 \%)$ neonates needed admission in NICU for MAS.
The presence of thick meconium amniotic fluid is associated with increased perinatal morbidity and mortality. Though sample size in our study is less but as per our study perinatal mortality can be reduced by amnioinfusion.

\section{CONCLUSION}

In developing countries with limited intrapartum facilities Amnioinfusion for meconium stained amniotic fluid improves perinatal outcome and decreases the caesarean section rates. In our study inrapartum amnioinfusion in meconium stained amniotic fluid resulted in reduction in caesarean section rate, significant reduction in meconium aspiration syndrome, low Apgar score and neodeath. So, from our study we can conclude that intrapartum amnioinfusion in meconium stained amniotic fluid by diluting the meconium and by decreasing the cord compression decreases the incidence of foetal distress and there by decreases the rate of caesarean section, these all leads to decrease the incidence of maternal and perinatal morbidity and mortality.

Funding: No funding sources

Conflict of interest: None declared

Ethical approval: Not required

\section{REFERENCES}

1. Wiswell TE, Bent RC. Meconium staining and meconium aspiration syndrome. Paediatr Clin North Am. 1993;40:995-81.

2. Katz VL, Bowes WA Jr. Meconium aspiration syndrome: reflections on a murky subject. Am J Obstet Gynecol. 1992;166:171-83.

3. Hofmeyr GJ. Amnioinfusion for meconium-stained liquor in labour. Cochr Database Syst Rev. 2002;(1).

4. Brown BL, Gleicher N. Intrauterine meconium aspiration. Obstet Gynecol. 1981:57:26-9.

5. Oyelese Y, Culin A, Ananth CV, Kaminsky LM, Vintzileos A, Smulian JC. Meconium-stained amniotic fluid across gestation and neonatal acidbase status. Obstet Gynecol. 2006;108(2):345-9.

6. Osava RH, Silva FM, Oliveira SM, Tuesta EF, Amaral MC. Meconium-stained amniotic fluid and maternal and neonatal factors associated. Revista de saude publica. 2013;46:1023-9.

7. Samiyappa D, Ghose S, John L, Samal R. Maternal and perinatal outcome in meconium stained amniotic fluid at term. A case control study. Int J Reprod Contracept Obstet Gynecol. 2016:3404-10.

8. Mukhopadhyay P, Naskar T, Dalui R, Hazra S, Guin $\mathrm{K}$, Bhattacharya D. Role of intrapartum amnioinfusion in meconium stained amniotic fluid. $\mathbf{J}$ Obstet Gynaecol India. 2006;56:230-2.

9. Asnani M, Singh S, Srivastava K, Gupta HP, Mittal A. Role of amnioinfusion in meconium stained liquor in relation to fetal outcome. Int J Reproduct, Contracept, Obstet Gynecol. 5(1):176. 
10. Sood M, Aggarwal N, Faridi MM. Amnioinfusion in thick meconium. Ind J Pediat. 2004;71(8):677-81.

11. Pierce J, Gaudier FL, Sanchez- Ramos L. Intrapartum amnioinfusion for meconium stained fluid: meta-analysis of prospective clinical trials. Obstet Gynecol. 2000;95:1051-6.

12. Hofmeyr GJ. Amnioinfusion for meconium-stained liquor in labour. Cochr Database Syst Rev. 2014.

13. Das AK, Jana N, Dasgupta S, Samanta B. Intrapartum transcervical amnioinfusion for meconium-stained amniotic fluid. Int J Gynecol Obstet. 2007;97(3):182-6.

14. Sahu IM. Intrapartum amnioinfusion in meconium stained amniotic fluid. J Obst Gyne Ind. 2003;53:345-7.
15. Mahomed K, Mulambo T, Woelk G, Hofmeyr GJ, Gülmezoğlu AM. The Collaborative Randomised Amnioinfusion for Meconium Project (CRAMP): 2. Zimbabwe. Br J Obstet Gynaecol. 1998;105(3);30913

16. Hofmeyr GJ. Amnioinfusion for meconium-stained liquor in labour. Cochrane Database Syst Rev. 2002;(1).

Cite this article as: Parihar BC, Yadav B, Sharde P, Patel J. Intrapartum amnioinfusion in meconium stained amniotic fluid at term pregnancy. Int J Reprod Contracept Obstet Gynecol 2021;10:97-101. 